g,PXYM

Genual Profesi Kesehatan Masyarakat

http://jurnal.bhmm.ac.id/index.php/jpkm

${ }^{\circledR}$ Corresponding Author.

email address : sagitamkes@gmail.com

Received : 20 Juli 2021 Revised : 23 Agustus 2021 Accepted : 15 Oktober 2021

\title{
Pengaruh Kegiatan Keterampilan Menganyam terhadap Peningkatan Perkembangan Motorik Halus Anak Prasekolah Usia 5-6 Tahun di TK Desa Pilangrejo Kecamatan Wungu Kabupaten Madiun
}

\author{
${ }^{\square}$ Sagita Haryati \& Karina Nur Ramadhanintyas \\ Stikes Bhakti Husada Mulia Madiun, Indonesia
}

\begin{abstract}
ABSTRAK
Perkembangan motorik merupakan perubahan progresif dalam perilaku motorik sebagai akibat interaksi antara faktor biologis dan pengalaman dalam siklus kehidupan manusia. Menganyam adalah jenis terapi yang dapat digunakan untuk meningkatkan kemmapuan motorik halus anak usia prasekolah. Penelitian ini bertujuan untuk mengetahui peningkatan perkembangan motorik halus anak usia prasekolah usia 5-6 tahun melalui ketrampilan menganyam di TK Desa Pilangrejo Kecamatan Wungu Kabupaten Madiun. Desain penelitian yang digunakan adalah Pra-Eksperimen dengan One Group Pre-post Test Design. Populasi dalam penelitian ini adalah seluruh anak di TK Desa Pilangrejo Kecamatan Wungu Kabupaten Madiun yang berjumlah 16 anak dengan kriteria inklusi. Alat ukur untuk mengukur perkembangan motorik halus menggunakan lembar observasi perkembangan motorik halus uji data yang digunakan yaitu uji Wilcoxon Signed Rank Test. Hasil perhitungan Wilcoxon Signed Rank Test menunjukkan bahwa hasil pretest lebih tinggi dibandingkan dengan hasil posttest. Sehingga hal ini berarti tidak terdapat peningkatan perkembangan motoric halus anak prasekolah usia 5-6 tahun setelah diberikan kegiatan menganyam. Kegiatan menganyam tidak dapat meningkatkan perkembangan motoric halus anak usia prasekolah. Penelitian lebih lanjut disarankan untuk memberikan stimulasi yang lebih banyak untuk hasil yang lebih akurat.
\end{abstract}

Kata kunci: Usia Prasekolah, Menganyam, Perkembangan Motorik Halus.

Effect of Weaking Skills Activities on Increasing Fine Motor Development of Preschool Children Aged 5-6 Years Old in TK Pilangrejo Village, Wungu District, Madiun Regency

\begin{abstract}
Motor development is a progressive change in motor behavior as a result of interactions between biological factors and experience in the human life cycle. Weaving is a type of therapy that can be used to enhance the fine motor ability of preschool age children. This research aims to determine the improvement of fine motor development of preschool age children aged 5-6 years through weaving skills at TK Pilangrejo Village, Wungu District, Madiun Regency.The research design used is pre-experimentation with One Group Pre-Post Test Design. The population in this study is the entire child in TK Pilangrejo Village, Wungu District, Madiun Regency which amounted to 16 children with inclusion criteria. Measuring instrument for measuring fine motor development using the fine motor Development observation sheet of the data test used is the Wilcoxon Signed Rank Test test. Wilcoxon Signed Ranks calculation showed result of the pretest are higher than posttest. This means that there is an increase in fine motor development in preschool aged 5-6 years after being given weaving activities. Weaving activities can 't improve the development of fine motor in preschool. Next research is advised using more than stimulation to get more accurate result.
\end{abstract}

Kata kunci: Preschool Age, Weaving, Fine Motoric Development.

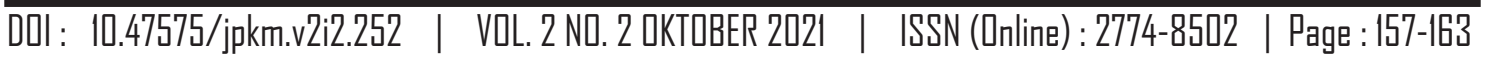




\section{PENDAHULUAN}

Masa anak usia dini merupakan masa yang paling potensial, dimana anak bergairah untuk banyak belajar dari pengalaman berbagai aktivitas yang menyebabkan perubahan pada dirinya, perubahan pada perkembangan kecerdasan anak yang berlangsung sangat pesat pada tahun-tahun awal kehidupannya (Ningsih, 2017). Kemampuan motorik salah satu proses tumbuh kembang yang harus dilalui dalam kehidupan anak, salah satunya motorik halus (Wulandari \& Hasibuan, 2017). Hasanah (2016) mengatakanbahwa proses pertumbuhan dan perkembangan dalam berbagai aspek sedang mengalami masa yang cepat dalam rentang perkembangan hidup manusia. Aspek perkembangan tersebut meliputi fisik motorik, kognitif, bahasa, seni, sosial emosional, nilai agama dan moral (Martika \& Mayar,2019). Perkembangan motorik ini erat kaitanya dengan perkembangan pusat motorik di otak. Oleh sebab itu, banyak ahli mengatakan bahwa perkembangan kemampuan motorik anak berhubungan dengan perkembangan kemampuan anak lainnya seperti perkembangan kognitif dan sosial emosional anak (Wulandari \& Hasibuan, 2017).

Perlu diketahui bahwasanya bila anak mengalami keterlambatan perkembangan maka anak akan mengalami autisme, retardasi mental, hiperaktif, gangguan bicara/berbahasa, sindroma down, dan gangguan perilaku (ADHD,ASD). Untuk mengetahui ada tidaknya keterlambatan perkembangan anak peneliti memiliki cara dengan melakukan kegiatan menganyam. Dalam kegiatan tersebut lebih ditekankan pada peran aktif anak sehingga dapat melatih keterampilan, merangsang aktivitas, mengasah mental menjadi tekun, telaten dan sabar. Semakin banyak stimulasi yang diberikan maka pengalaman anak semakin optimal.

Berdasarkan latar belakang diatas, maka peneliti merasa tertarik untuk meneliti tentang Pengaruh Kegiatan Keterampilan Menganyam Terhadap Peningkatan Perkembangan Motorik Halus Anak Prasekolah Usia 5-6 Tahun di TK Desa Pilangrejo Kecamatan Wungu Kabupaten Madiun.

\section{METODE PENELITIAN}

Penelitian ini menggunakan Desain penelitian Pra-Eksperimental dengan menggunakan onegroup pre-post test design. Populasi dalam penelitian ini adalah Semua siswa-siswi di TK Desa Pilangrejo Kecamatan Wungu Kabupaten Madiun yang berusia 5-6 tahun dengan jumlah 16 anak. Besar sampel ditentukan dengan rumus perhitungan sempel dengan menggunakan teknik total sampling di dapatkan sebanyak 16 orang responden.

Variabel Independen dalam penelitian ini adalah keterampilan menganyam, sedangkan variabel dependent adalah motorik halus.

Alat ukur atau instrumen yang digunakan dalam penelitian ini adalah Kuesioner Pra-Skrining Perkembangan (KPSP) merupakan suatu instrument deteksi dini dalam perkembangan anak usia 0 sampai 6 tahun (Diana,2015). KPSP adalah alat atau instrument yang digunakan untuk mengetahui perkembangananak normal atau ada penyimpangan (Karusdianti,2018).

\section{HASIL DAN PEMBAHASAN}

Tabel 1

Distribusi Frekuensi Responden Berdasarkan Usia Orang Tua

\begin{tabular}{clcc}
\hline No & $\begin{array}{l}\text { Usia } \\
\text { (tahun) }\end{array}$ & $\begin{array}{c}\text { Jumlah } \\
(\mathrm{F})\end{array}$ & $\begin{array}{c}\text { Presentase } \\
(\%)\end{array}$ \\
\hline 1 & $17-25$ & 1 & 6,3 \\
2 & $26-35$ & 10 & 62,5 \\
3 & $36-45$ & 5 & 31,3 \\
& Jumlah & 16 & 100.0 \\
\hline
\end{tabular}

Sumber: Data Diolah, 2021

Tabel 2

Distribusi Frekuensi Responden Berdasarkan Pendidikan Orang Tua

\begin{tabular}{clcc}
\hline No & Pendidikan & $\begin{array}{c}\text { Jumlah } \\
(\mathrm{F})\end{array}$ & $\begin{array}{c}\text { Presentase } \\
(\%)\end{array}$ \\
\hline 1 & SMP & 2 & 12,5 \\
2 & SMA & 10 & 62,5 \\
3 & Perguruan & 4 & 25,0 \\
& Tinggi & & \\
& Jumlah & 16 & 100.0 \\
\hline
\end{tabular}

Sumber: Data Diolah, 2021 
Tabel 3

Distribusi Frekuensi Responden Berdasarkan Pekerjaan Orang Tua

\begin{tabular}{clcc}
\hline No & Pekerjaan & $\begin{array}{c}\text { Jumlah } \\
(\mathrm{F})\end{array}$ & $\begin{array}{c}\text { Presentase } \\
(\%)\end{array}$ \\
\hline 1 & IRT & 6 & 37,5 \\
2 & Swasta & 1 & 6,3 \\
3 & Wiraswasta & 6 & 37,5 \\
4 & PNS & 3 & 18,8 \\
& Jumlah & 16 & 100 \\
\hline
\end{tabular}

Sumber: Data Diolah, 2021

Tabel 4

Distribusi Frekuensi Responden (Anak) Berdasarkan Jenis Kelamin

\begin{tabular}{clcc}
\hline No & Jenis Kelamin & $\begin{array}{c}\text { Jumlah } \\
(\mathrm{F})\end{array}$ & $\begin{array}{c}\text { Presentase } \\
(\%)\end{array}$ \\
\hline 1 & Laki-laki & 8 & 50,0 \\
2 & Perempuan & 8 & 50,0 \\
& Jumlah & 16 & 100 \\
\hline
\end{tabular}

Sumber: Data Diolah, 2021

Tabel 5

Distribusi Frekuensi Responden (Anak) Berdasarkan Usia

\begin{tabular}{cccc}
\hline No & Usia & $\begin{array}{c}\text { Jumlah } \\
(\mathrm{F})\end{array}$ & $\begin{array}{c}\text { Presentase } \\
(\%)\end{array}$ \\
\hline 1 & 60 bulan & 5 & 31,2 \\
2 & 66 bulan & 6 & 37,5 \\
3 & 72 bulan & 5 & 31,2 \\
& Jumlah & 16 & 100 \\
\hline
\end{tabular}

Sumber: Data Diolah, 2021

Tabel 6

Hasil Analisis dari Perkembangan

Motorik Halus Anak Sebelum Diberikan Keterampilan Menganyam

\begin{tabular}{ccc}
\hline Kelompok & & Statistic \\
\hline Pre menganyam & Mean & 1.56 \\
& Std. & .512 \\
& Deviation & \\
& Minimum & 1 \\
& Maximum & 2 \\
\hline
\end{tabular}

Sumber: Data Diolah, 2021
Tabel 7

Hasil Analisis dari Perkembangan

Motorik Halus Anak Sesudah Diberikan Keterampilan Menganyam

\begin{tabular}{ccc}
\hline Kelompok & & Statistic \\
\hline Post menganyam & Mean & 1.06 \\
& Std. & .250 \\
& Deviation & \\
& Minimum & 1 \\
& Maximum & 2 \\
\hline
\end{tabular}

Sumber: Data Diolah, 2021

Tabel 8

Hasil Pengaruh Perkembangan Motorik

Halus Anak Sebelum dan Sesudah

Diberikan Keterampilan Menganyam

\begin{tabular}{ccccc}
\hline Kelompok & & $\mathrm{N}$ & $\begin{array}{c}\text { Mean } \\
\text { Ranks }\end{array}$ & $\begin{array}{c}\text { Sum of } \\
\text { Ranks }\end{array}$ \\
\hline Post-test & $\begin{array}{c}\text { Negative } \\
\text { ranks }\end{array}$ & $8^{\mathrm{a}}$ & 4.50 & 36.00 \\
Pre-test & $\begin{array}{c}\text { Positive } \\
\text { ranks }\end{array}$ & $0^{\mathrm{s}}$ & .00 & .00 \\
& $\begin{array}{c}\text { Ties } \\
\text { Total }\end{array}$ & $8^{\mathrm{c}}$ & & \\
& 16 & & \\
\hline
\end{tabular}

Sumber: Data Diolah, 2021

\section{PEMBAHASAN}

Perkembangan Motorik Halus Anak Sebelum Diberikan Kegiatan Keterampilan Menganyam di TK Desa Pilangrejo Kecamatan Wungu Kabupaten Madiun

Berdasarkan tabel 6, menunjukkan bahwa sebelum diberikan keterampilan menganyam mendapatkan hasil nilai rata-rata sebesar 1.56, standart devisiasi sebesar .512, nilai minimal 1 dan nilai maksimal 2. Orang tua anak yang mayoritas bekerja sebagai wiraswasta yang harus berangkat kerja pagi hari sehingga orang tua tidak bisa memperhatikan anak dengan sepenuhnya. Namun ada sebagian anak yang orang tuanya bekerja sebagai ibu rumah tangga dan orang tua bisa memperhatikan semaksimal mungkin. Pekerjaan orang tua juga mempengaruhi perkembangan motorik anak, dapat diketahui pekerjaan orang tua sebagian besar adalah wiraswasta 6 orang $(37,5 \%)$. 
Secara umum perkembangan motorik halus pada anak usia 5 tahun dan 6 tahun meliputi menggunting dengan baik, menuliskan beberapa huruf dan angka menggunakan pergelangan tangannya untuk menggerakkan ujung pensil (Febriana \& Kusumaningtyas, 2018).

Menurut Febriana \& Kusumaningtyas (2018), perkembangan motorik halus adalah perkembangn otot-otot tangan anak untuk melakukan beberapa gerakan yang membutuhkan koordinasi seperti meremas kertas, memegang benda tertentu, menulis menyobek kertas atau kegiatan apapun yang memerlukan keterampilan tangan. Perkembangan motorik halus adalah kemampuan yang melibatkan koordinasi mata dan tangan untuk melakukan gerakan-gerakan secara halus (Soetjiningsih, 2012).

Sesuai dengan teori Wulandari \& Hasibuan (2017), dimana perkembangan motorik halus anak usia 5-6 tahun mampu mengembangkan kemampuan motorik halus yang berhubungan dengan keterampilan gerak kedua tangan, mampu menggerakkan anggota tubuh yang berhubungan dengan gerak jari jemari seperti kesiapan menulis, menggambar dan memanipulasi benda-benda, mampu mengkoordinasikan indra mata dan aktivitas tangan serta mampu mengendalikan emosi dalam beraktivitas motorik halus.

Penelitian yang dilakukan oleh Taju dkk. (2015), didapatkan hasil bahwa perkembangan motorik halus anak dipengaruhi oleh pekerjaan orang tua. Kehadiran orang tua dalam kehidupan sehari-hari anak lebih sebentar dibandingkan dengan orang tua yang tidak bekerja, sehingga kesempatan orang tua untuk memberikan motivasi dan stimulasi dalam anak melakukan tugas perkembangan motorik terbatas.

Menurut asumsi peneliti, sebagian siswa dari TK Desa Pilangrejo Kecamatan Wungu Kabupaten Madiun memiliki perkembangan motorik halus yang belum sesuai. Hal ini terjadi akibat pola asuh orang tua yang kurang tepat serta kurangnya perhatian orang tua tentang perkembangan motorik halus anak. Sebagian besar pekerjaan orang tua peserta didik sebagai wiraswasta yang biasa berangkat kerja selalu pagi dan pulang terlalu larut malam sehingga kesempatan untuk memperhatikan perkembangan peserta didik lebih sedikit. Hal ini tentu menjadi perhatian bagi semua pihak untuk meningkatkan pengetahuan orang tua tentang pentingnya perkembangan pada anak.

\section{Perkembangan Motorik Halus Anak Sesudah Diberikan Kegiatan Keterampilan Menganyam di TK Desa Pilangrejo Kecamatan Wungu Kabupaten Madiun}

Berdasarkan tabel 7, menunjukkan bahwa sesudah diberikan keterampilan menganyam mendapatkan hasil nilai rata-rata sebesar 1.06, standart devisiasi sebesar .250 , nilai minimal 1 dan nilai maksimal 2.

Faktor umur mempengaruhi perkembangan motorik halus. Berdasarkan hasil penelitian menunjukkan bahwa sebagian besar responden berumur 66 bulan berjumlah 6 responden $(37,5 \%)$. Meskipun dapat terjadipada semua kelompok umur perkembangan motorik halus memang sering dianggap terjadi diumur pertengahan. Perkembangan motorik halus juga dapat terjadi pada semua jenis kelamin namun faktanya perkembangan motorik halus lebih sering terjadi pada perempuan karena anak perempuan lebih sering melatih keterampilan yang membutuhkan keseimbangan tubuh, seperti permainan melompati tali atau melompat-lompat dengan bola besar (Febriana \& Kusumaningtyas, 2018).

Stimulasi juga dapat mempengaruhi perkembangan motorik halus. Contohnya kemampuan memindahkan benda dari tangan, mencoret-coret, menyusun balok, menggunting dan menulis.

Menurut Aghnaita (2016), Seorang anak pada tahap ini masih heran terhadap perubahan yang terjadi pada tubuhnya dan dorongandorongan yang menyertai perubahan tersebut. Pada tahap ini, anak mengalami perubahan perkembangan motorik.

Menurut asumsi peneliti setelah dilakukan posttest dan pemberian stimulasi belumterjadi perubahan pada responden. Hal itu terjadi akibat kurangnya diberikan stimulasi terutama pada stimulasi yang membutuhkan keseimbangan otot-otot tangan maupun mata. Hal ini tentu menjadi perhatian bagi orang tua untuk tetap meningkatkan stimulasi agar perkembangan motorik halus anak semakin berkembang. 
Analisa Pengaruh Kegiatan Keterampilan Menganyam Terhadap Peningkatan Perkembangan Motorik Halus Anak Prasekolah Usia 5-6 Tahun di TK Desa Pilangrejo Kecamatan Wungu Kabupaten Madiun

Tingkat perkembangan motorik halus sebelum diberikan kegiatan keterampilan menganyam adalah nilai rata-rata sebesar 1.56 , standart devisiasi sebesar .512, nilai minimal 1 dan nilai maksimal 2, dan sesudah diberikan kegiatan keterampiln menganyam adalah nilai rata-rata sebesar 1.06, standart devisiasi sebesar .250, nilai minimal 1 dan nilai maksimal 2 .

Perubahan ini menunjukkan, kegiatan keterampilan menganyam tidak berpengaruh terhadap peningkatan perkembangan motorik halus prasekolah usia 5-6 tahun. Hasil analisa perkembangan motorik halus sebelum dan sesudah diberikan kegiatan keterampilan menganyam dengan uji Wilcoxon Sign Rank Test. Berdasarkan uji statistik diperoleh nilai negative ranks sebesar $8^{\mathrm{a}}$ yang artinya hasil pretest lebih tinggi dibandingkan hasil posttest, nilai positive sebesar $0^{5}$ yang artinya hasil posttestlebih tinggi dibandingkan pretest, dan nilai ties sebesar $8 c$ yang artinya hasil pretest sama dengan hasil posttest. Sehingga $\mathrm{H}_{0}$ diterima dan $\mathrm{H}_{1}$ ditolak yang artinya tidak terdapat pengaruh kegiatan keterampilan menganyam terhadap peningkatan perkembangan motorik halus anak prasekolah usia 5-6 tahun di TK Desa Pilangrejo Kecamatan Wungu Kabupaten Madiun.

Hasil ini dapat terjadi karena hasil sesudah kegiatan keterampilan menganyam semua responden mendapatkan nilai lebih rendah dibandingkan dengan hasil nilai sebelum diberikan stimulasi. Bila dilihat menggunakan uji Wilcoxon Signed Rank Test didapatkan hasil bahwa kegiatan keterampilan menganyam tidak berpengaruh dalam meningkatkan kemampuan motorik halus anak prasekolah usia 5-6 tahun. Hal tersebut terjadi karena penelitian yang dilakukan hanya sekali. Sehingga untuk menghasilkan pengaruhnya dalam meningkatkan kemampuan motoric halus sangat kecil.

Faktor yang mempengaruhi kegiatan keterampilan menganyam adalah pekerjaan ibu responden yaitu wiraswasta dan PNS. Ibu responden merupakan wanita karir yang memiliki peran ganda sebagai ibu rumah tangga. Dampak negatif dari ibu yang bekerja adalah tidak dapat memberikan perhatian yang penuh pada anaknya ketika anak dalam masa tumbuh kembang yang pesat (Chamidah, 2015). Saat dilakukan kegiatan keterampilan menganyam anak tersebut sering berlarian di dalam dan luar kelas meninggalkan kegiatan yang diberikan, sehingga kegiatan keterampilan menganyam yang dibuat hasilnya kurang maksimal. Sebagian besar anak bermain bersama teman yang dikenalnya serta anak mengeluh bosan saat dipertengahan kegiatan keterampilan menganyam. Konsentrasi anak tidak berfokus pada kegiatan keterampilan menganyam yang peneliti lakukan. Selain itu ada faktor yang mempengaruhi kegiatan keterampilan menganyam adalah usia anak. Pada anak usia dini merupakan golden age (masa peka) yaitu waktu yang paling tepat untuk memberikan bekal yang kuat kepada anak untuk menggali segala potensi kecerdasan anak sebanyakbanyaknya (Maghfiroh \& Andajani, 2018). Pada saat melakukan kegiatan keterampilan menganyam anak aktif dalam berinteraksi dengan penelitian dan mengikuti instruksi yang diberikan peneliti. Hal ini bisa terjadi karena anak yang aktif berinteraksi dan rasa ingin tahu terhadap kegiatan keterampilan menganyam yang ingin dilakukan oleh dirinya sendiri serta anak berkonsentrasi dalam mengikuti instruksi peneliti untuk melakukan kegiatan keterampilan menganyam. Pengalaman kegiatan keterampilan menganyam lebih nyata dan lebih disukai oleh anak-anak dan anak lebih bersemangat untuk membuat kreasi menganyam sesuai tema.

Febriana \& Kusumaningtyas (2018), mengatakan bahwa menganyam adalah kerajinan tradisional yang dilakukan dengan cara menyusupkan bagian-bagian pita anyaman secara bergantian. Kegiatan keterampilan menganyam ini membutuhkan koordinasi yang cermat serta ketelitian. Keterampilan menganyam dapat melatih otot-otot tangan atau jari, koordinasi otot dan mata, memupuk perasaan terhadap gerakan tangan dan memupuk keindahan.

Menurut Hurlock (2011), anak yang banyak mendapat stimulasi akan lebih cepat berkembang dari pada anak yang kurang 
atau bahkan tidak mendapat stimulasi. Salah satu bentuk keuntungan pemberian kegiatan keterampilan menganyam adalah meningkatkan keterampilan dan kreativitas anak sehingga perkembangan anak akan semakin terasah. Hasil penelitian ini menunjukkan bahwa anak yang memperoleh banyak stimulasi atau rangsangan yang diperoleh dari para guru pengajar atau dari fasilitasyang disediakan oleh pihak sekolah, dimana dengan rangsangan tersebut anak akan semakin terasah dan perkembangan akan semakin baik dan sesuai dengan usia anak.

\section{SIMPULAN}

Perkembangan motorik halus anak sebelum diberikan kegiatan keterampilan menganyam pada anak usia 5-6 tahun di TK Desa Pilangrejo

Kecamatan Wungu Kabupaten Madiun menunjukkan bahwa sebelum diberikan keterampilan menganyam mendapatkan hasil nilai rata-rata sebesar 1.56 , standart devisiasi sebesar .512, nilai minimal 1 dan nilai maksimal 2. Perkembangan motorik halus anak sesudah diberikan kegiatan keterampilan menganyam pada anak usia 5-6 tahun di TK Desa Pilangrejo Kecamatan Wungu Kabupaten Madiun menunjukkan bahwa sesudah diberikan keterampilan menganyam mendapatkan hasil nilai rata-rata sebesar 1.06, standart devisiasi sebesar .250, nilai minimal 1 dan nilai maksimal 2. Tidak ada pengaruh yang signifikan antara kegiatan keterampilan menganyam terhadap perkembangan motorik halus anak prasekolah usia 5-6 tahun di TK Desa Pilangrejo Kecamatan Wungu Kabupaten Madiun.

\section{DAFTAR PUSTAKA}

Adriana, Dian. 2013. Tumbuh Kembang dan Terapi pada Anak. Jakarta: Salemba Medika.

Arikunto. 2011. Prosedur Penelitian Suatu Pendekatan Praktik. Jakarta : PT. Rineka Cipta.
Atmaja, Hadi Kusuma. 2018. Perkembagan Motorik Anak Usia 3-5 Tahun di Raudatul Atfal Addinul-Qayyim Desa Gunungsari Kecamatan Gunungsari Kaupaten Lombok Barat Tahun 2017. Jurnal Kesehatan Almuslim, 3(6).

Chamidah. 2015. Deteksi Dini Gangguan Pertumbuhan Dan Perkembangan Anak.

Dewi, Rizki Cintya. 2015 . Teori \& Konsep Tumbuh Kembang Bayi, Toddler, Anak dan Usia Remaja. Yogyakarta : Nuha Medika.

Dewi, Ni Kadek Ari \& Suara, Made. 2015. Metode Pemberian Tugas Berbantuan Media Konkret Kegiatan Menganyam Kertas Untuk Meningkatkan Kemampuan Motorik Halus Anak. Jurnal Pendidikan Anak Usia Dini, 2(1). http:// dx.doi.org/10.23887/paud.v2i1.3235.

Febriana, Anggita., \& Kusumaningtyas, Lydia. 2018. Meningkatkan Motorik Halus Anak Melalui Kegiatan Menganyam Pada Anak Kelompok B Usia 5-6 Tahun. Jurnal AUDI, 2(2). http://dx.doi. org/10.33061/ad.v2i2.1971.

Hasanah, Uswatun. 2016. Pengembangan Kemampuan Fisik Motorik Melalui Permainan Tradisional Bagi Anak Usia Dini. Jurnal Pendidikan Anak, 5(1). Terdapat dalam https://doi.org/10.21831/ jpa.v5i1.12368.

IDAI. 2012. Pemantauan Tumbuh Kembang Anak. Tersedia dalam http:// dokumen. tips/documents/rekomendasi-idaipemantauan-tumbuhkembang anak.pdf. html.

Maghfiroh, Laila., \& Andajani, Sri. 2018. Pengaruh Keterampilan Dasar Menganyam Enceng Gondok Terhadap Kemapuan Motorik Halus Anak Usia 5-6 Tahun di TK Aisyiyah Bustanul Athfal 03 Kadet Suwoko Lamongan. Jurnal PAUD Teratai, 7(1). 
Mandasari, 2016. Kreasi Kerajinan dari Bambu. Jawa Barat : Khalifah Mediatama.

Martika, Junia Sri., \& Mayar, Farida. 2019. Pengaruh Kegiatan Menganyam Kain Flanel Terhadap Kemampuan Motorik Halus Anak di PAUD Tunas Bangsa Padang. Jurnal Caksana Pendidikan Anak Usia Dini, 2(1). https://doi. org/10.31326/jcpaud.v2i1.365.

Mawrah, Silvi, Abubakar, Sitti. 2019. Meningkatkan Kemapuan Motorik Halus Anak Melalui Teknik Menganyam Daun Kelapa di Kelompok B TKN Putra Mandiri Konawe Selatan. . Jurnal Smart PAUD, 2(2). http://dx.doi.org/10.36709/ jspaud.v2i2.7287.

Ningrum, Muhima. 2015. Meningkatkan Kemampuan Motorik Halus Anak Melalui Kegiatan Menganyam di Kelompok B TK ABA II Pantoloan. Laporan Tugas Akhir, Universitas Tadulako, Palu. Terdapat dalam http:// jurnal.untad.ac.id/jurnal/index.php/ Bungamuti/article/view/7237.

Ningsih, Ninik. 2017. Peningkatan Keterampilan Motorik Halus Anak Melalui Kegiatan Mengayam dengan Berbagai Media Pada Kelompok A2. Jurnal Pendidikan Anak Usia Dini, 7(6). http://journal.student.uny.ac.id/ojs/ojs/ index.php/pgpaud/article/view/7925/0

Notoatmodjo. 2012. Metode Penelitian Kesehatan. Jakarta: Rineka Cipta.

Nugroho, H.S.W.2009. Denver developmental screening test. Jakarta: EGC.
Nursalam. 2016. Metodologi Penelitian Ilmu Keperawatan: Salemba Medika, Jakarta.

Potter \& Perry, AG 2005. Buku Ajar Fundamental Keperawatan: Konsep, Proses, dan Praktik. Edisi 4. Volume 1. Jakarta: EGC.

Kementrian Kesehatan Republik Indonesia. 2016. Profil Kesehatan Indonesia. https://pusdatin.kemkes.go.id/article/ view/16091600001/profil-kesehat anindonesia-tahun-2015.html.

Rohendi, A. 2017. Perkembangan Motorik. Bandung : Alfabeta.

Soetjiningsih. 2012. Tumbuh Kembang Edisi 2. Jakarta : EGC.

Sugiyono. 2013. Metode Penelitian Pendidikan. Bandung : Alfabeta.

Sujarweni, V.W. 2014. Metodologi Penelitian Keperawatan. Yogyakarta: Gava Medika.

Sulistiyswati. 2014. Deteksi Tumbuh Kembang Anak. Jakarta : Salemba Medika.

Wulandari, Yuni., \& Hasibuan, Rachma. 2017. Peningkatan Kemampuan Motorik Halus Melalui Kegiatan Menganyam Pada Anak Kelompok A Di TK Dharma Bhakti Kepuhrejo Kudu Jombang. Jurnal PAUD Teratai 6(3).

Wulansari, Tri \& Khotimah, Nurul. 2016. Meningkatkan Kemampuan Motorik Halus Anak Melalui Kegiatan Menganyam Pita di Kelompok A. Jurnal PAUD Teratai, 5(1). 